\title{
Research on Financial Early Warning of Private Listed Companies Based on Z-score Model
}

\author{
Wen $\mathrm{Mu}$ \\ Business School \\ Sichuan University \\ Chengdu, China
}

\author{
Meng Liu \\ Business School \\ Sichuan University \\ Chengdu, China
}

\begin{abstract}
Chinese private economy is an important force to promote economic and social development. President $\mathrm{Xi}$ Jinping pointed out in his speech at the private enterprise symposium that it is necessary to help the private economy to develop and grow better. However, Chinese private enterprises are still affected by problems such as financing difficulties, and they still face the problems of rapid deterioration of financial situation and financial crisis. Therefore, this paper studies the financial indicators of some private listed companies, so as to play a certain early warning role before private enterprises enter the financial dilemma.
\end{abstract}

Keywords-private enterprise; financial early warning; Zscore model

\section{INTRODUCTION}

The financial crisis can put the entire enterprise in a difficult position, and even cause it to go bankrupt without ever turning to self-help. The private economy is an indispensable force in China's economic development. The state has also introduced various measures to support private enterprises in reform and development. However, the financial status of private enterprises is not as good as that of state-owned enterprises, especially due to difficulties in financing and inadequate financial structure, making it easier to face financial crisis. The financial crisis is not suddenly formed, but a process of gradual change. This paper establishes a financial early warning model for private listed companies by studying the changes of some financial indicators. For a long time, scholars have little research on the financial early warning of private enterprises. This paper constructs an effective financial early warning model to quantitatively predict and analyze private listed companies, and provides theoretical and technical support for their sustainable and healthy development.

Fitzpatrick (1932) [1] The first study found that he compared the financial data of 19 listed companies and found that the financial ratio of companies in financial distress is significantly different from that of normal companies, so that the financial ratio of the company can reflect its Self-financial status, and pointed out that the financial ratio has a predictive effect on the future of the company. Beaver (1966) [2] based on this, using mathematical statistics method to establish a univariate financial early warning model, with 79 financial failure enterprises and 79 between 1956 and 1964 The non-failed enterprises are sampled and analyzed on the basis of the five years before the failure. The debt cash ratio, return on assets, asset-liability ratio and asset security ratio are the four most effective financial indicators for predicting corporate crises. The forecasting effect of the company's financial position is good, followed by the forecasting effect of asset yield and asset-liability ratio.

The representative of the multivariate analysis model is the $\mathrm{Z}$ model, which is a bankruptcy prediction model designed by the famous financial expert Edward Altman (1968) [3]. The method is to construct a multivariate linear equation that can classify the sample company with the smallest classification error rate through linear regression technique. When the discriminant, the company's independent variable value is returned to the discriminant equation, and the equation value is used as the standard pair. Whether the company failed to judge.

Ohlson (1980) [4] first used the Logit model for financial early warning. He selected 105 bankrupt companies and 2058 non-bankrupt companies from 1970 to 1976 to form an unpaired sample, analyzing the distribution of sample companies in the ruin probability interval and analysing the relationship between two types of discriminating errors and dividing points.

Odom and Sharda (1990) [5] were the first to apply the artificial neural network model (ANN) to financial early warning, using a three-layer feedforward ANN, using the same five financial ratios in the $\mathrm{Z}$ model, and using the MDA model as the standard.

Jie Sun (2013) [6] selected 30 financial indicators data of 135 pairs of listed companies in Shanghai and Shenzhen stock markets, using financial intelligence single classifier, multi-classifier combination and group decision-based method for financial early warning method research. This proposes to build a multi-level financial early warning system and introduce the combined thinking into the field of financial crisis prediction.

Zhixiang Liu (2016) [7] selected 41 ST companies and 41 non-listed companies listed in the Shanghai and Shenzhen stock markets as of the end of 2013 as a research sample, using principal component analysis, with financial data for 2012-2014 as Based on empirical analysis, through the 
exploration of the adaptability of financial early warning models in listed companies in China.

\section{INTRODUCTION TO THE Z-SCORE MODEL}

In 1968, Edward Altman established the famous Z-score model of five variables. Its expression is:

$$
\mathrm{Z}=1.2 \mathrm{X} 1+1.4 \mathrm{X} 2+3.3 \mathrm{X} 3+0.6 \mathrm{X} 4+0.999 \times 5 \text {, }
$$

where $\mathrm{X} 1=$ (current assets - current liabilities) $/$ total assets,

$\mathrm{X} 2$ = retained earnings / total assets,

$\mathrm{X} 3=($ total profit + financial expenses $) /$ total Assets,

$\mathrm{X} 4=$ (stock market value $*$ total number of shares $) /$ total liabilities,

$\mathrm{X} 5=$ sales $/$ total assets.

Professor Atman determined the critical value $Z=2.675$ through statistical analysis. If $\mathrm{Z}<2.675$, the borrower would default; if $Z>2.675$, the borrower would be classified as nondefault. At the same time, when $Z<1.81$, the company is facing a financial crisis and is divided into bankruptcy; when $\mathrm{Z} \leq 2.99$, the probability of bankruptcy in this year is $95 \%$, and the probability of bankruptcy within two years is $70 \%$. Uncertainty is divided into gray areas; when $Z>2.99$, enterprises generally do not go bankrupt and are classified as safe areas.

In 2000, Professor Atman revised the $\mathrm{Z}$ model, eliminating the total asset turnover rate, which is a very sensitive indicator of the industry, and obtained the Z3 model, thus minimizing the potential impact of the $\mathrm{Z}$ model on the industry. Its expression is:

$$
\mathrm{Z} 3=6.65(\mathrm{X} 1)+3.26(\mathrm{X} 2)+6.72(\mathrm{X} 3)+1.05
$$$$
\text { (X4) }
$$

Where $\mathrm{X} 1$ = working capital / total assets

$\mathrm{X} 2=$ Retained earnings/total assets

$\mathrm{X} 3=\mathrm{EBIT}$ before interest/total assets

X4=Shareholders' equity/total liabilities

When $\mathrm{Z} 3<1.23$, it indicates that the enterprise may go bankrupt at any time and faces a serious financial crisis; when $\mathrm{Z3}>2.9$, it indicates that the possibility of bankruptcy is small and is in a safe area; when $1.23 \leq \mathrm{Z} 3 \leq 2.9$, it indicates that the enterprise is at In the undetermined gray area, bankruptcy or not can't be judged, and further observation and research is needed.

The Z-score model is simple to operate, independent of the collinearity of the independent variables and has high accuracy. Therefore, the multivariate is used to construct the Z-score model to help enterprises analyze the financial situation quickly and easily.

It can be seen from the above literature review that although there are many studies on the financial early warning model, this kind of research has not been embodied, and it is rare to study the financial early warning model in combination with the industry. It can be seen that the existing research results at home and abroad are not enough to be applied to private enterprises. This paper intends to conduct an empirical analysis of the financial early warning system of private listed companies, so that private enterprises can have reference when establishing a financial early warning system.

\section{APPLICATION OF Z-SCORE MODEL}

\section{A. Sample Selection}

The article is a financial early warning study for private listed companies. In the 2015-2017 Shanghai Stock Exchange, a total of 36 private listed companies were specially treated for ST for the first time, eliminating 2 companies with B shares and incomplete financial data. The 34 ST companies were studied as samples. In order to better carry out comparative analysis, 34 non-ST groups with similar asset size were selected from non-ST private listed companies, and two sets of 2015-2017 annual report data were selected for research. The data referenced in the article came from the CSMAR database.

\section{B. Modeling}

According to the index frequency selected by 43 documents, the selected financial early warning indicators are shown in "Table I".

TABLE I.

FINANCIAL INDICATORS

\begin{tabular}{|l|l|l|l|l|}
\hline \multicolumn{1}{|c|}{ Solvency capacity } & \multicolumn{1}{|c|}{ Operational capability } & \multicolumn{1}{|c|}{ Development capability } & \multicolumn{1}{|c|}{ Profitability capability } & \multicolumn{1}{c|}{ Cash flow } \\
\hline X1 current ratio & $\begin{array}{l}\text { X7 accounts receivable } \\
\text { turnover rate }\end{array}$ & X11 capital accumulation rate & X16 return on assets & $\begin{array}{l}\text { X21 operating income cash } \\
\text { content }\end{array}$ \\
\hline X2 quick ratio & X8 inventory turnover rate & X12 total asset growth rate & $\begin{array}{l}\text { X17 total asset net profit } \\
\text { margin }\end{array}$ & X22 total cash recovery rate \\
\hline X3 Cash Ratio & X9 Current Asset Turnover & X13 Net Profit Growth Rate & X18 Return on Assets & $\begin{array}{l}\text { X23 Cash Reinvestment } \\
\text { Ratio }\end{array}$ \\
\hline $\begin{array}{l}\text { X4 Asset-liability } \\
\text { ratio }\end{array}$ & $\begin{array}{l}\text { X10 Total asset turnover } \\
\text { rate }\end{array}$ & $\begin{array}{l}\text { X14 Owner equity growth } \\
\text { rate }\end{array}$ & $\begin{array}{l}\text { X19 Return on invested } \\
\text { capital }\end{array}$ & XX24 Operating indeX \\
\hline X5 equity ratio & $\begin{array}{l}\text { X15 net flow growth rate per } \\
\text { share of operating activities }\end{array}$ & X20 cost expense margin & $\begin{array}{l}\text { X25 operating profit cash net } \\
\text { content }\end{array}$ \\
\hline $\begin{array}{l}\text { X6 interest coverage } \\
\text { multiple }\end{array}$ & & & \\
\hline
\end{tabular}


Since the selected samples are divided into ST groups and non-ST groups, it is necessary to perform nonparametric tests on two independent samples to determine whether there is a significant difference between them. Therefore, the Mann-Whitney $\mathrm{U}$ method is selected for non-parametric tests. After using the Mann-Whitney U test, the cash ratio, interest guarantee multiple, accounts receivable turnover rate, capital accumulation rate, and net flow growth rate per share of operating activities were screened out. Total asset growth rate, owner's equity growth rate, return on assets, net profit margin of total assets, return on net assets, return on invested capital, profit margin of cost and expense, total cash recovery rate, and cash reinvestment ratio Significant differences in indicators.

The 14 variables were then subjected to stepwise discriminant analysis using Wilks' Lambda. The results are shown in "Table II".

TABLE II. WILKS' LAMBDA

\begin{tabular}{|c|c|c|c|c|}
\hline $\begin{array}{c}\text { Function } \\
\text { test }\end{array}$ & $\begin{array}{c}\text { Wilks' } \\
\text { Lambda }\end{array}$ & Bangla & $\begin{array}{c}\text { Degree of } \\
\text { freedom }\end{array}$ & Sig. \\
\hline 1 & .125 & 45.565 & 3 & .001 \\
\hline
\end{tabular}

The value of Wilks' Lambda is 0.125 , close to 0 , indicating that the difference between the groups is large, the discriminant analysis is meaningful, and the significance is 0.001 far below 0.05 , which is suitable for discriminant analysis.

Through further discriminant analysis, only the significant level of the total cash recovery rate, return on assets, and total net profit margin is lower than the established level of 0.05 , which is significant.

TABLE III. STANDARD SPECIFICATION DisCRIMINANT FunCTION COEFFICIENT

\begin{tabular}{|c|c|}
\hline \multirow{2}{*}{ Cash Ratio } & Function \\
\cline { 2 - 2 } & 1 \\
\hline total asset net profit margin & .262 \\
\hline Return on invested capital & 3.455 \\
\hline
\end{tabular}

It can be concluded from the above "Table III" that the expression of the Z-score model of the financial warning of private listed companies is: $\mathrm{Z}=0.262 * \mathrm{X} 22+3.455 * \mathrm{X} 17$ $2.674 * \mathrm{X} 16$, where $\mathrm{X} 22$ is the total cash recovery rate and $\mathrm{X} 17$ is the total net profit of the assets. Rate, X16 is the rate of return on assets.

Substituting the model into ST and non-ST companies, the $\mathrm{Z}$ values of the two groups can be obtained. The average value of the ST group is -0.080 , the mean square error is 0.077 , the average value of the non-ST group is 0.012 , and the mean square error is 0.078 . Using the hypothesis test method in mathematical statistics, assuming that the $Z$ value obeys the t-distribution of the significance level $\alpha=0.05$, then the lower limit of $\mathrm{Z}$ value for the ST group company is $\alpha=0.05$ :

$$
\begin{aligned}
& \mathrm{Zmin}=\mathrm{Z}-\quad(\mathrm{S} / \sqrt{ } \mathrm{n}) * \mathrm{t} 0.95 \quad(\mathrm{n}-1) \\
& \mathrm{Zmin}=-0.080-\quad(0.077 / \sqrt{ } 34) * 1.693 \\
& =-0.1435
\end{aligned}
$$

The upper limit of $Z$ value for $\alpha=0.05$ for non-ST group companies is:

$$
\begin{aligned}
& \mathrm{Z} \max =\mathrm{Z}+(\mathrm{S} / \sqrt{ } \mathrm{n}) * \mathrm{t} 0.95(\mathrm{n}-1) \\
& \mathrm{Z} \max =0.012+(0.078 / \sqrt{ } 34) * 1.693 \\
& =0.0346
\end{aligned}
$$

The author takes the center of the upper and lower limits - 0.0544 as the boundary point between the two groups, and divides the $\mathrm{Z}$ value into four levels according to the above results. (See "Table IV")

TABLE IV. Z VALUE RANKING

\begin{tabular}{|l|c|c|c|}
\hline $\mathbf{Z}$ value division & $\begin{array}{c}\text { Financial } \\
\text { risk }\end{array}$ & $\begin{array}{c}\text { Crisis } \\
\text { possible }\end{array}$ & $\begin{array}{c}\text { Warning } \\
\text { indication }\end{array}$ \\
\hline$>-\mathbf{0 . 0 1 1}$ & safe & Very unlikely & safe \\
\hline $\mathbf{- 0 . 0 3 4 5 < Z \leqslant - 0 . 0 1 1}$ & a bit safe & $\begin{array}{c}\text { Possibly } \\
\text { small }\end{array}$ & $\begin{array}{c}\text { Mild } \\
\text { warning }\end{array}$ \\
\hline $\mathbf{- 0 . 0 5 8}<\boldsymbol{Z} \leqslant \mathbf{0 . 0 3 4 5}$ & Risk & Possibility & $\begin{array}{c}\text { Moderate } \\
\text { warning }\end{array}$ \\
\hline$<-\mathbf{0 . 0 5 8}$ & High risk & Very likely & High alert \\
\hline
\end{tabular}

\section{Logistic Regression Test}

According to the above division of financial risk status, the sample data is brought into the Z-score model for selftest, and the test results are shown in the "Table V".

TABLE V. LOGISTIC REgRESSION TEST RESUlt

\begin{tabular}{|c|c|c|c|c|}
\hline & & $\begin{array}{c}\text { Financially } \\
\text { safe }\end{array}$ & $\begin{array}{c}\text { Financial } \\
\text { risk }\end{array}$ & Accuracy \\
\hline \multirow{2}{*}{ Counting } & ST & 4 & 30 & $88.23 \%$ \\
\cline { 2 - 5 } & Non-ST & 28 & 6 & $82.35 \%$ \\
\hline $\begin{array}{c}\text { Total } \\
\text { correct rate }\end{array}$ & & & & $85.29 \%$ \\
\hline
\end{tabular}

\section{CONCLUSION AND SUGGESTION}

Through nonparametric test and discriminant analysis, this paper establishes a financial early warning model suitable for private listed companies. Through the analysis of private enterprises, it makes more targeted measures to improve the financial status of enterprises.

It can be seen from the Z-score model that private enterprises can improve the $\mathrm{Z}$ value, and the measures that can be taken are:

\section{A. Increasing Net Cash Flow from Operating Activities}

Private enterprises should improve their operational efficiency, strengthen the management of accounts receivable, reduce the total amount of accounts receivable, reduce the collection period of accounts receivable, and recover accounts receivable in a timely manner. This also 
reduces unnecessary expenses incurred in the collection of receivables, thereby reducing financial costs.

\section{B. Increasing Corporate Net Profit}

Improve the sales of products of private enterprises and reduce the cost of products, but they cannot blindly expand. This is easy to face financial crisis due to financial breaks; enterprises should also strengthen tax planning and try to avoid taxation as much as possible, which is conducive to the sustainable development of private enterprises.

\section{Reducing Corporate Finance Costs}

The financial expenses of private enterprises are mainly the expenses incurred in financing, and the problem of financing difficulties has always been a mountain that hinders the development of private enterprises. Private enterprises can expand financing channels through commercial paper financing and borrowing from non-bank financial institutions. They can also make full use of national preferential policies to reduce financing costs.

\section{REFERENCES}

[1] Fitzpatrick,P.J. A Comparison of Ratios of Successful Industrial Enterprises with Those of Failed Firms [J]. Certified Public Accountant, 1932:11-15.

[2] Beaver,W.H. Financial Ratios as Predictors of Failure [J]. Journal of Accounting Research, 1967:71-95.

[3] Altman,E. Financial Ratios Discriminate Analysis and Prediction of Corporate Bankruptcy [J]. Journalof Finance, 1968:589-609.

[4] Ohlson,J.A. Financial Rations and the Probabilistic Prediction of Bankruptcy [J]. Journal of Accounting Research, 1980:109-131.

[5] Odom, R Sharda. A neural network models for Bankruptcy prediction [J]. Neural Networks, 1990:163-167.

[6] Jie Sun. Intelligent Decision Method for Enterprise Financial Crisis Early Warning [M]. Beijing: China Social Sciences Press, 2015: 1-18.

[7] Zhixiang Liu. Construction and Application of Financial Early Warning Model for Chinese Listed Companies [M]. Beijing: China Business Press, 2016: 34-122.

[8] Yang Chao. Research on the Construction of Enterprise Financial Early Warning System [J]. Friends of Accounting, 2016(6): 55-57.

[9] Wang Jinghua. Problems and Countermeasures of Financial Management in Private. Enterprises [J]. Accounting Science and Technology, 2019(8): 31-31+33 